\title{
Physicochemical assessment of industrial textile effluents of Punjab (India)
}

\author{
Deepika Bhatia ${ }^{1}$ Neeta Raj Sharma ${ }^{1} \cdot$ Ramesh Kanwar $^{2} \cdot$ Joginder Singh $^{1}[$
}

Received: 16 April 2017 / Accepted: 15 May 2018 / Published online: 22 May 2018

(c) The Author(s) 2018

\begin{abstract}
Urbanization and industrialization are generating huge quantities of untreated wastewater leading to increased water pollution and human diseases in India. The textile industry is one of the leading polluters of surface water and consumes about 200-270 tons of water to produce 1 ton of textile product. The primary objective of the present study was to investigate the pollution potential of textile industry effluent draining into Buddha Nallah stream located in Ludhiana, Punjab (India), and determine the seasonal variation in physicochemical parameters $(\mathrm{pH}$, water temperature, total dissolved solids, total suspended solids, biochemical oxygen demand (BOD) and chemical oxygen demand (COD) of Buddha Nallah water. During summer months, for Site 1 and Site 2, the value of $\mathrm{pH}$ was in the alkaline range of $8.78 \pm 0.47$ and $8.51 \pm 0.41$, respectively. The values of $\mathrm{pH}$ in the rainy season were found to be in the range of $7.38 \pm 0.58$ and $7.11 \pm 0.59$ for Site 1 and Site 2, respectively. In the autumn and winter seasons, the average $\mathrm{pH}$ values were found to be in the range of $8.58 \pm 1.40$ and $8.33 \pm 0.970$, respectively. The maximum mean temperature in summer was recorded as $41.16 \pm 4.99^{\circ} \mathrm{C}$, and lowest mean temperature in winter was recorded as $39.25 \pm 2.25^{\circ} \mathrm{C}$ at Site 2 . The suspended solids were found to be highest $(143.5 \pm 75.01$ and $139.66 \pm 71.87 \mathrm{mg} / \mathrm{L})$ in autumn for both the sites and lowest $(86.50+15.10 \mathrm{mg} / \mathrm{L})$ in the rainy season for Site 1 . The values of BOD and COD of the textile effluent of both sites during all the seasons ranged from 121-580 to 240-990 mg/L, respectively, much higher than WHO water quality standard of $30 \mathrm{mg} / \mathrm{L}$ for BOD and $250 \mathrm{mg} / \mathrm{L}$ for COD. The present study deals with the collection of textile industry effluent and its characterization to find out the physicochemical load being drained by the effluent generated from textile industries, on the natural wastewater streams.
\end{abstract}

Keywords Wastewater $\cdot$ Textile effluent $\cdot$ Physicochemical parameters $\cdot$ Pollution

\section{Introduction}

Freshwater is the key to sustain life on earth. With the advent of human civilization, proliferating population, the industrial revolution and rapid urbanization, aquatic assets are getting employed as dumping ground for industrial waste, sewage and domestic waste. There is no denial of the fact that nature has a fascinating endowment to confront small amount of wastewater and water pollution, but it would be venturesome if the huge amount of untreated wastewater gets discharged to natural water bodies. The receiving water

Joginder Singh

joginder.15005@lpu.co.in

1 School of Bioengineering and Biosciences, Lovely Professional University, Phagwara, Punjab 144411, India

2 Office of the Vice Chancellor, Lovely Professional University, Phagwara, Punjab 144411, India bodies and drains carry precarious industrial effluents which affect the quality of water and aquatic ecosystem and human life (Singh et al. 2016; Mishra et al. 2016; Kumar et al. 2013, 2014a, b, 2015a, b). The textile industry in India is one of the most important and most polluting industries in terms of consumption and generation of huge amounts of wastewater, fuel and diverse group of chemicals such as dyes (Asia et al. 2006; dos Santos et al. 2007; Verma et al. 2012). It is reported that more than 8000 synthetic chemical products are associated with different processing steps of dye (Bhatia et al. 2017). There are approximately 10,000 chemicalbased dyes found in nature with a global annual production of almost $7 \times 10^{5}$ metric tons (Khataee and Kasiri 2010). To operate different processes such as resizing, scouring, bleaching, dyeing and printing of fabric, a vast amount of water is used and waste is generated (Ghaly et al. 2014). The main issue of effluent from textile industries with environmental problems is the elevation of biochemical oxygen 
demand (BOD), chemical oxygen demand (COD), $\mathrm{pH}$, suspended solids in water bodies (Wang et al. 2011). The treatment of textile effluent prior to its release into water bodies is must as pollution traits such as solids, oils, metal complexes, high organics, complex synthetic dyes and residues from various pre-processing steps for fabric preparation and colouring have far-reaching environmental ramification. Thus, the pollution caused by the textile effluents has become a critical concern because it poses a serious threat to the environment and human health (Sarker et al. 2015).

The major aesthetic problem of the textile effluent is colour, due to voluminous use of synthetic organic compounds as dyes. Chromophores, having an azo bond $(-\mathrm{N}=\mathrm{N}-)$, may be mono-azo, di-azo, and poly-azo; $-\mathrm{C}=\mathrm{O} ;-\mathrm{N}=\mathrm{O}$, etc., are responsible for colouring properties of dyes (Chaube et al. 2010). The remittance of untreated textile effluent including liquid, gaseous and solid wastes leads to severe environmental problems, affecting the aquatic ecosystem by reducing the penetration of sunlight and thus by decreasing the rate of photosynthesis and increasing biological oxygen demand (Kant 2012; Singh et al. 2015). The natural stream of water, in turn, leads to a fatal effect on fishes and suppresses the growth of microorganisms (Puvaneswari et al. 2006).

The effluent discharged from the textile industries is of great environmental concern since it reduces the oxygen concentration in water due to the presence of hydrosulfide group compounds. Also, it blocks the passage of light through the water body and is detrimental to the water ecosystem (Khan and Malik 2014). Textile effluent is a cause of human illnesses. About $40 \%$ of textile dyes contain organically bound chlorine, which is a known carcinogen. Chemicals evaporate into the air and get absorbed by our skin and cause allergic reactions to children before birth. Due to this chemical pollution, the normal functioning of cells is interrupted. This may cause an alteration in the physiology and biochemical mechanisms of animals, resulting in impairment of important functions like respiration, osmoregulation, reproduction and even mortality (Rawat et al. 2016). Heavy metals, present in textile dyes as a chromophoric group, are not biodegradable; hence, they accumulate in primary organs in the body and lead to various symptoms of diseases (Dadi et al. 2017). Thus, untreated or incompletely treated textile effluent can be harmful to both aquatic and terrestrial life by adversely affecting the natural ecosystem and causing long-term health effects (Chung 2016).

Many bioassays have been used to monitor and assess the toxicity of wastewater from domestic and various industries (Hader 2018). The efficiency of wastewater effluent treatment plants can be determined by monitoring the water samples from the inlet and after each treatment step (physical, chemical and biological), as well as from the outlet of the plant. Microbial degradation is generally considered as a safe, cost-effective and reliable technique for pesticides elimination from the environmental compartments (Singh et al. 2017a, b; Mishra et al. 2016; Kumar et al. 2017). Abbas et al. (2018) and Iqbal (2016) discussed the use of Vibrio fischeri bioluminescence inhibition bioassay (VFBIA) and Vicia faba bioassay, respectively, for monitoring of toxicity of wastewater due to its sensitivity and ease of operation. Textile wastewater has been studied by using $V$. faba bioassay to detect the contaminant load (Giorgetti et al. 2011). They reported that raw textile effluents showed higher cytogenic and mutagenic effects as well in comparison to treated effluents. The risk assessment of textile industrial areas of Faisalabad city was studied by Noreen et al. (2017). They used various bioassays, viz. cytotoxicity assay (haemolytic and brine shrimp assays), to monitor the ecological risk of the contaminated area. The main contributing sources and type of operations that generate SOx emissions from petroleum industry have been reviewed by Jafarinejad (2016). These studies have found that sulphur compounds are a major precursor of acid rain. The quality of groundwater has also been assessed for vulnerability potential to dumpsite pollution using a modified DRASTIC (DRALTC) model (Majolagbe et al. 2016; Majolagbe et al. 2017). This study demonstrated that a DRASTIC model is a good tool in environmental management and sustainability. The mathematical model equation has also been developed by Ukpaka (2016) to predict the fate of contaminant in the environment and quality of groundwater. The polynomial curve was established to ascertain the validity of a model equation. Studies to analyse different pollution parameters of the main channels of wastewater collecting tributaries and various water streams are utmost required. Analysis of wastewaters on the basis of physical, chemical and biological parameters is needed for the investigation of pollution potential and thus to embrace the necessary treatment options. Keeping in mind, the present study has been conducted to assess the quality of the effluent of selected textile industries of Ludhiana, which are located in the vicinity of Buddha Nallah, Ludhiana, India. Effluents being discharged from textile units of Ludhiana are the major sources of pollution at the receiving drain of Buddha Nallah. Through this study, an attempt has been made to determine pollution of this local drain.

\section{Materials and methods}

\section{Glassware and chemicals}

All glassware used during the course of experiments was of "A" grade calibrated quality (Borosil India, New Delhi, India), and chemicals were of analytical reagent (AR) grade (Loba Chemie, Mumbai, India). Double distilled water was used throughout the experimental work. 


\section{Study area}

Punjab is one of the arable and leading states in India, with a highly developed agriculture system, well-equipped infrastructure and a high human development index with industrious, painstaking and entrepreneur skills. It accounts for almost $1.53 \%$ of India's geographical area and $2.37 \%$ of its population. It represents a unique example of a fast developing economy based on agriculture. Ludhiana, the hub of hosiery, the metropolitan centre of Punjab, has emerged as the most vibrant and important business centre. Positioned at $30^{\circ} 56{ }^{\prime} \mathrm{N}$ and $75^{\circ} 52^{\prime} \mathrm{E}$, Ludhiana is located about $10 \mathrm{~km}$ south of the Sutlej, one of the five major rivers of pre-independent Punjab. The Sutlej river and its tributary, a perennial stream, the Buddha Nallah originates near Chamkaur Sahib in Ropar district and enters Ludhiana city near village Bholapur. The Buddha Nallah drain flows through the city and is flooding stream during the monsoon season, which carries the domestic and industrial sewage of the city, finally merges into Sutlej River. The month of July is considered as the wettest month with an average of $90.8 \mathrm{~mm}$ of rainfall compared to the month of November, driest weather with an average of $0.0 \mathrm{~mm}$ of rainfall. This was concluded by analysing seasonal data recorded by Climate Change and Agricultural Meteorology Department, Punjab Agricultural University, Ludhiana.

\section{Sampling}

Wastewater samples were collected in the morning hours between 7 and 9 am twice a month from April 2014 to 2015. Samples were taken on a monthly basis, i.e. a total of 48 times during the period of investigation. For each major season representing rainy monsoon, summer, autumn and winter, 48 samples were collected on fixed dates with suitable intervals (15 days) from two different textile dyeing industries, viz. Site 1 and Site 2 located on Tajpur and Bahadur Ke Road, Ludhiana, India (Fig. 1). The month-wise rainfall data in $\mathrm{mm}$ were collected from Climate Change and Agricultural Meteorology Department, Punjab Agricultural University, Ludhiana. Wastewater was collected in sterilized glass bottles labelled with sample code and transported to the laboratory in an ice box. Collected wastewater samples were kept cool, at $4{ }^{\circ} \mathrm{C}$, but not frozen.

\section{Analysis of physicochemical parameters of water samples}

After sampling, the analysis was started immediately in the laboratory. The standard methods recommended by APHA (2005) and Trivedy and Goel (1984) were employed for the determination of various physicochemical parameters like $\mathrm{pH}$, temperature, total dissolved solids (TDS), total suspended solids (TSS), biochemical oxygen demand (BOD) and chemical oxygen demand (COD). $\mathrm{pH}$ of the effluent samples was determined by the electrometric method by using a digital desktop, $\mathrm{pH}$ meter (Systronics-335). The temperature was determined by glass thermometer. Similarly, TDS and TSS were analysed by the gravimetric method by using evaporating dishes and Whatman filter paper no. 1 having pore size $11 \mu \mathrm{m}$. The COD test and $\mathrm{BOD}_{5}$ were analysed by modified Winkler's method in $300-\mathrm{mL}$ BOD bottles.

\section{Statistical analysis}

In order to identify the relationship among different physicochemical parameters, the data were pooled for four seasons: rainy monsoon season (June 2014-August 2014), autumn season (September 2014-November 2014), winter season (December 2014-February 2015) and summer season (March 2015-May 2015), respectively. An average of 48 analytical values of each sampling with respect to selected parameters in a particular season has been taken as observed value. The observed values have been taken for subsequent statistical analysis and interpretation. The differences between the physicochemical parameters for both the sites were evaluated by Student's unpaired $t$ test. Statistical analysis was done with the help of IBM SPSS version 16.0 (Chicago, USA) computer software programs. The experimental data are presented as mean \pm SD of the replicate experiment at $* p \leq 0.05$.

\section{Results}

Discharge of treated and untreated effluents by the textile industries disturbs the environmental integrity of this region. Two textile dyeing industries nominated as Site 1 and Site 2 have been selected that is located in the vicinity of Buddha Nallah drain, Tajpur Road and Bahadur Ke Road, Ludhiana, to perform the objective of the study. The results of the physicochemical properties of effluent collected from the two selected sites are given in Table 1. The mean and standard deviation of seasonal variation of physicochemical parameters, such as $\mathrm{pH}$, temperature, TDS, BOD, COD and TSS, were investigated from two selected sites of Ludhiana for the year 2014-2015 (Tables 2, 3).

The $\mathrm{pH}$ of the collected textile effluent sample from selected sites was analysed and found in the range between 6.1 and 10.7, respectively, against the standard of WHO and IS 10500:1991, i.e. 6.5-8.5. Figure 2 shows the mean seasonal variation of $\mathrm{pH}$ of two sites along with the mean season rainfall. Seasonal analysis of effluents showed variation in the values of $\mathrm{pH}$ for different textile effluents. For Site 1 , in the summer season, the value of $\mathrm{pH}$ was in the 
Fig. 1 The map of Ludhiana showing the sampling sites (Site 1 and Site 2, shown in red) on Buddha Nallah drain

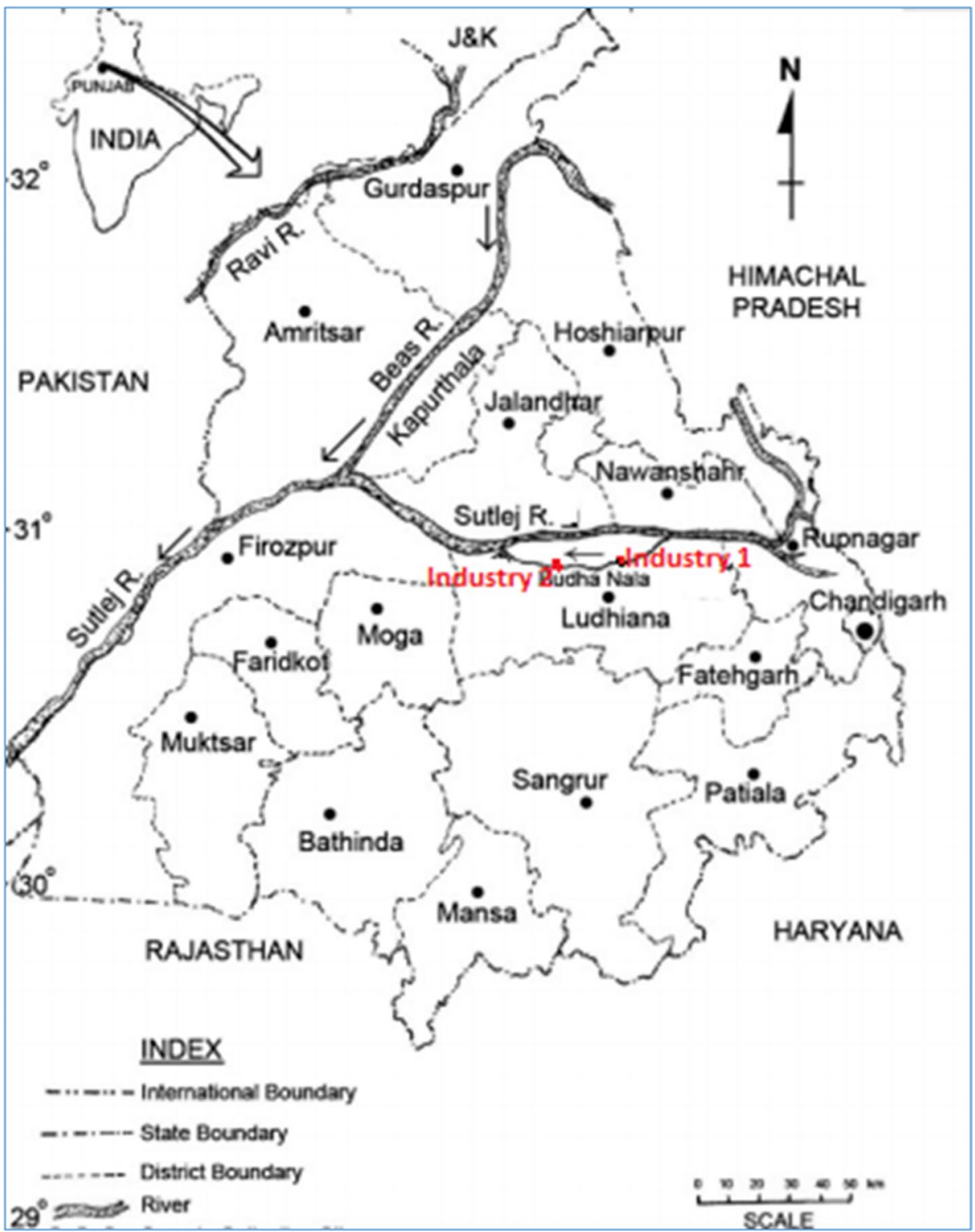

alkaline range of $8.78 \pm 0.470(p<0.05)$ which is highly significant with similar trends for Site 2 , in the range of $8.51 \pm 0.411$. The values of $\mathrm{pH}$ in the rainy season for Site 1 were found to be in the range of $7.38 \pm 0.583$ as compared to the $\mathrm{pH}$ of the effluent coming from Site 2, i.e. $7.11 \pm 0.598$ which shows the non-significant difference. Effluent from Site 1, in autumn and winter season, showed alkaline values of $\mathrm{pH}$ in the range of $8.58 \pm 1.40$ and $8.33 \pm 0.970$, respectively. Similar results were obtained after the analysis of effluent of Site 2. The important parameter which affects many chemical and biological processes occurring in water is temperature. The effect of temperature is related to season and sampling time. In the present investigation, variation in values of water temperature was observed. The maximum mean temperature was recorded in summer, i.e. $41.16 \pm 4.99{ }^{\circ} \mathrm{C}$, and lowest mean temperature in winter, i.e. $39.25 \pm 2.25^{\circ} \mathrm{C}$ at Site
2 in contrary, and the maximum mean temperature was recorded in the rainy season and minimum in autumn, i.e. $40.83 \pm 2.42$ and $37.66 \pm 2.58{ }^{\circ} \mathrm{C}$, respectively. Figure 3 shows the mean seasonal variation of the temperature of two sites along with the mean season rainfall. The water temperature of industries was studied between two seasons, rainy and winter. During the rainy monsoon season, the highest temperature of $45.1{ }^{\circ} \mathrm{C}$ was observed. Highly significant seasonal fluctuations in the values of dissolved solids have been observed. The mean value of TDS was highest in autumn $2783 \pm 321.26 \mathrm{mg} / \mathrm{L}(p<0.05)$ significantly different, and lowest is $1456 \pm 153.06 \mathrm{mg} / \mathrm{L}$ in winter for the effluent collected from Site 1. Similar trends were observed in the effluent of Site 2, the maximum value of TDS in autumn, i.e. $2678 \pm 346.68 \mathrm{mg} / \mathrm{L}$ which is highly significant $(p<0.05)$, and minimum in winter season, i.e. $1463.8 \pm 164.22 \mathrm{mg} / \mathrm{L} ; 1618.5 \pm 180.03 \mathrm{mg} / \mathrm{L}$ 


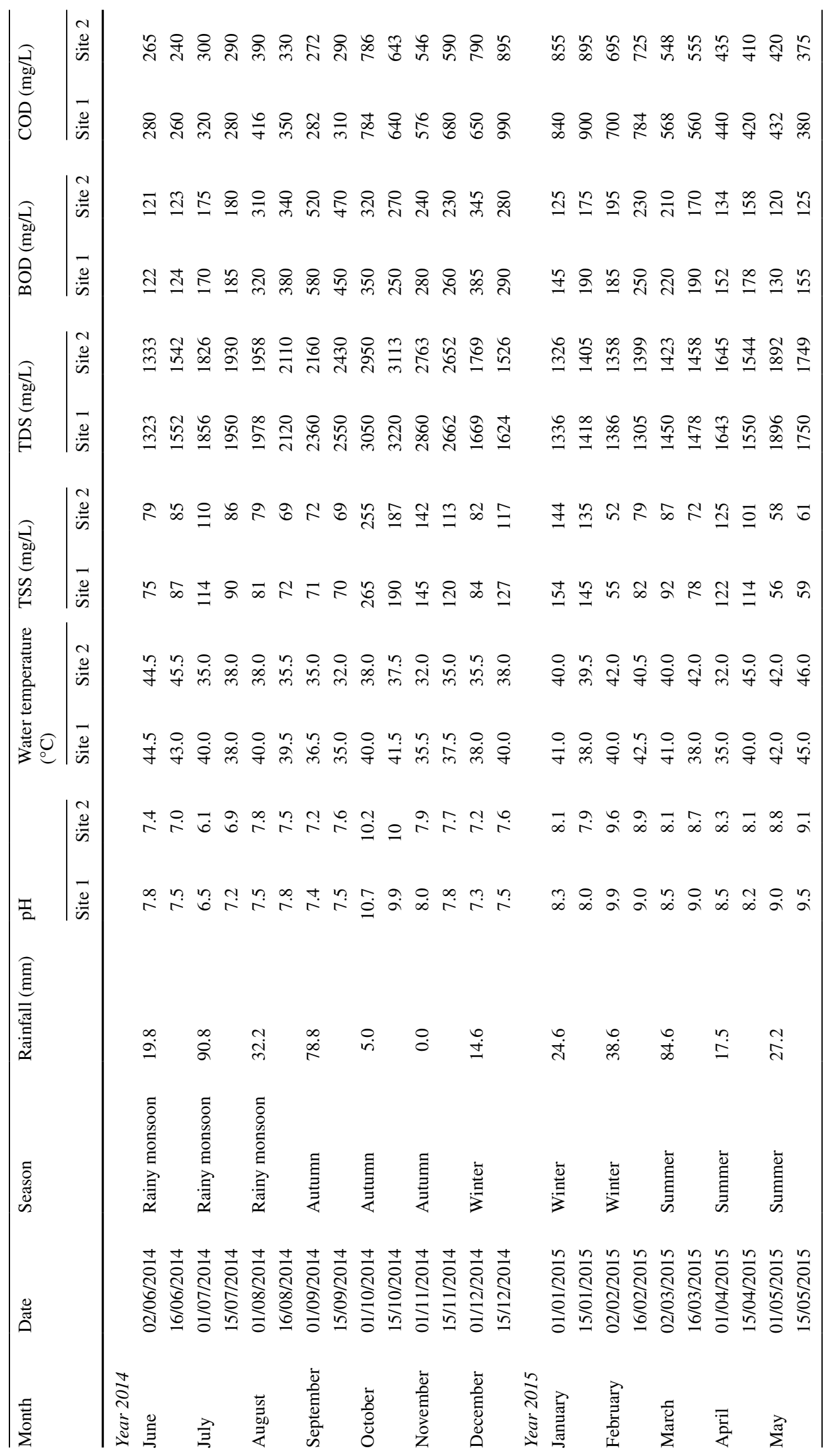


Table 2 Seasonal fluctuations in physicochemical parameters at Site 1 from June 2014 to May 2015

\begin{tabular}{|c|c|c|c|c|c|c|c|c|c|}
\hline \multirow[t]{2}{*}{ Parameters } & \multirow{2}{*}{$\begin{array}{l}\text { WHO } \\
\text { standard }\end{array}$} & \multicolumn{2}{|c|}{ Summer $($ mean $\pm S D)$} & \multicolumn{2}{|c|}{ Rainy monsoon (mean \pm SD) } & \multicolumn{2}{|c|}{ Autumn $($ mean \pm SD) } & \multicolumn{2}{|l|}{ Winter $($ mean \pm SD $)$} \\
\hline & & Site 1 & $\begin{array}{l}p \text { value (two } \\
\text { tailed) }\end{array}$ & Site 1 & $\begin{array}{l}p \text { value } \\
\text { (two } \\
\text { tailed) }\end{array}$ & Site 1 & $\begin{array}{l}p \text { value (two } \\
\text { tailed) }\end{array}$ & Site 1 & $\begin{array}{l}p \text { value (two } \\
\text { tailed) }\end{array}$ \\
\hline $\mathrm{pH}$ & $6.5-8.5$ & $8.78 \pm 0.470$ & $0.024^{*}$ & $7.38 \pm 0.487$ & 0.810 & $8.58 \pm 1.40$ & 0.165 & $8.33 \pm 0.970$ & 0.190 \\
\hline $\begin{array}{l}\text { Total } \\
\quad \text { suspended } \\
\text { solids } \\
(\mathrm{mg} / \mathrm{L})\end{array}$ & $100 \mathrm{mg} / \mathrm{L}$ & $86.83 \pm 27.58$ & $0.026^{*}$ & $86.50 \pm 15.10$ & 0.053 & $143.5 \pm 75.01$ & 0.185 & $107.8 \pm 39.76$ & 0.63 \\
\hline $\begin{array}{l}\text { Total dis- } \\
\text { solved } \\
\text { solids } \\
\text { (mg/L) }\end{array}$ & $2000 \mathrm{mg} / \mathrm{L}$ & $1627.8 \pm 171.58$ & $0.000 *$ & $1796.5 \pm 299.55$ & 0.120 & $2783.7 \pm 321.26$ & $0.00 *$ & $1456.3 \pm 153.06$ & $5.60 \mathrm{E} 0-6^{*}$ \\
\hline $\begin{array}{c}\text { Chemical } \\
\text { oxygen } \\
\text { demand } \\
(\mathrm{mg} / \mathrm{L})\end{array}$ & $250 \mathrm{mg} / \mathrm{L}$ & $466.67 \pm 78.20$ & $0.00004 *$ & $317.67 \pm 58.10$ & $0.010^{*}$ & $545.33 \pm 204.80$ & $0.00 *$ & $810.67 \pm 126.31$ & $7.35 \mathrm{E}-07 *$ \\
\hline $\begin{array}{c}\text { Biological } \\
\text { oxygen } \\
\text { demand } \\
(\mathrm{mg} / \mathrm{L})\end{array}$ & $30 \mathrm{mg} / \mathrm{L}$ & $170.83 \pm 96$ & $7.87 \mathrm{E}-07^{*}$ & $216.83 \pm 107.78$ & $0.000^{*}$ & $361.67 \pm 130.44$ & $9.78 \mathrm{E}-05^{*}$ & $240.83 \pm 87.37$ & $0.000^{*}$ \\
\hline $\begin{array}{l}\text { Water tem- } \\
\text { perature } \\
\left({ }^{\circ} \mathrm{C}\right)\end{array}$ & $\begin{array}{c}\text { Not exceed } \\
40{ }^{\circ} \mathrm{C}\end{array}$ & $40.16 \pm 3.43$ & 0.907 & $40.83 \pm 2.42$ & 0.419 & $37.66 \pm 2.58$ & 0.051 & $39.91 \pm 1.74$ & 0.901 \\
\hline
\end{tabular}

${ }^{*} p<0.05$ (highly significant)

Table 3 Seasonal fluctuations in physicochemical parameters at Site 2 from June 2014 to May 2015

\begin{tabular}{|c|c|c|c|c|c|c|c|c|c|}
\hline \multirow[t]{2}{*}{ Parameters } & \multirow{2}{*}{$\begin{array}{l}\text { WHO } \\
\text { standard }\end{array}$} & \multicolumn{2}{|c|}{ Summer $($ mean $\pm S D)$} & \multicolumn{2}{|c|}{ Rainy monsoon (mean $\pm \mathrm{SD})$} & \multicolumn{2}{|c|}{ Autumn $($ mean $\pm \mathrm{SD})$} & \multicolumn{2}{|l|}{ Winter $($ mean \pm SD) } \\
\hline & & Site 2 & $\begin{array}{l}p \text { value (two } \\
\text { tailed) }\end{array}$ & Site 2 & $\begin{array}{l}p \text { value } \\
\text { (two } \\
\text { tailed) }\end{array}$ & Site 2 & $\begin{array}{l}p \text { value } \\
\text { (two } \\
\text { tailed) }\end{array}$ & Site 2 & $p$ value (two tailed) \\
\hline $\mathrm{pH}$ & $6.5-8.5$ & $8.51 \pm 0.411$ & 0.059 & $7.11 \pm 0.598$ & 0.469 & $8.43 \pm 1.31$ & 0.210 & $8.21 \pm 0.88$ & 0.240 \\
\hline $\begin{array}{l}\text { Total sus- } \\
\text { pended } \\
\text { solids } \\
(\mathrm{mg} / \mathrm{L})\end{array}$ & $100 \mathrm{mg} / \mathrm{L}$ & $84.00 \pm 25.79$ & 0.159 & $84.66 \pm 13.80$ & $0.021^{*}$ & $139.66 \pm 71.87$ & 0.206 & $101.5 \pm 36.07$ & 0.920 \\
\hline $\begin{array}{c}\text { Total dis- } \\
\text { solved } \\
\text { solids } \\
(\mathrm{mg} / \mathrm{L})\end{array}$ & $2000 \mathrm{mg} / \mathrm{L}$ & $1618.5 \pm 180.03$ & $0.000^{*}$ & $1783.1 \pm 290.37$ & 0.097 & $2678 \pm 346.68$ & $0.000 *$ & $1463.8 \pm 164.22$ & $1.18137 \mathrm{E}-05^{*}$ \\
\hline $\begin{array}{c}\text { Chemical } \\
\text { oxygen } \\
\text { demand } \\
(\mathrm{mg} / \mathrm{L})\end{array}$ & $250 \mathrm{mg} / \mathrm{L}$ & $457.16 \pm 75.72$ & $5.35578 \mathrm{E}-05^{*}$ & $302.5 \pm 52.70$ & $0.034 *$ & $521.16 \pm 202.90$ & $0.008 *$ & $809.16 \pm 86.39$ & $2.05 \mathrm{E}-08^{*}$ \\
\hline $\begin{array}{c}\text { Biological } \\
\text { oxygen } \\
\text { demand } \\
(\mathrm{mg} / \mathrm{L})\end{array}$ & $30 \mathrm{mg} / \mathrm{L}$ & $152.83 \pm 34.04$ & $4.88 \mathrm{E}-06^{*}$ & $208.16 \pm 94.33$ & $0.000^{*}$ & $341.66 \pm 123.84$ & $0.000 *$ & $225 \pm 78.54$ & $0.000^{*}$ \\
\hline $\begin{array}{l}\text { Water tem- } \\
\text { perature } \\
\left({ }^{\circ} \mathrm{C}\right)\end{array}$ & $\begin{array}{c}\text { Not exceed } \\
40{ }^{\circ} \mathrm{C}\end{array}$ & $41.16 \pm 4.99$ & 0.579 & $39.41 \pm 4.51$ & 0.751 & $34.91 \pm 2.57$ & $0.000 *$ & $39.25 \pm 2.25$ & 0.909 \\
\hline
\end{tabular}

${ }^{*} p<0.05$ (highly significant)

in summer and $1783.1 \pm 290.37 \mathrm{mg} / \mathrm{L}$ in rainy monsoon (Fig. 4). Overall, the TDS values were higher in autumn and monsoon, while within the desirable limits of WHO in winter. In the present investigation, the value of suspended solids was recorded in autumn for two industries, i.e. $143.5 \pm 75.01$ and $139.66 \pm 71.87 \mathrm{mg} / \mathrm{L}$, respectively, which is more than the permissible limit given by
WHO, and minimum were recorded in rainy season, i.e. $86.50 \pm 15.10 \mathrm{mg} / \mathrm{L}$ for Site 1 and $84 \pm 27.59 \mathrm{mg} / \mathrm{L}$ for Site 2 in summer. Figure 5 shows us the season variation of TSS. BOD indicates the presence of organic impurities in the effluent. Figure 6 clearly shows us that the values for BOD of the effluent of two sites are more than the permissible limits set by WHO. In the present study, 
Fig. 2 Average seasonal variations of $\mathrm{pH}$ at different seasons of Site 1 and Site 2 Ludhiana, Punjab (April 2014-2015)
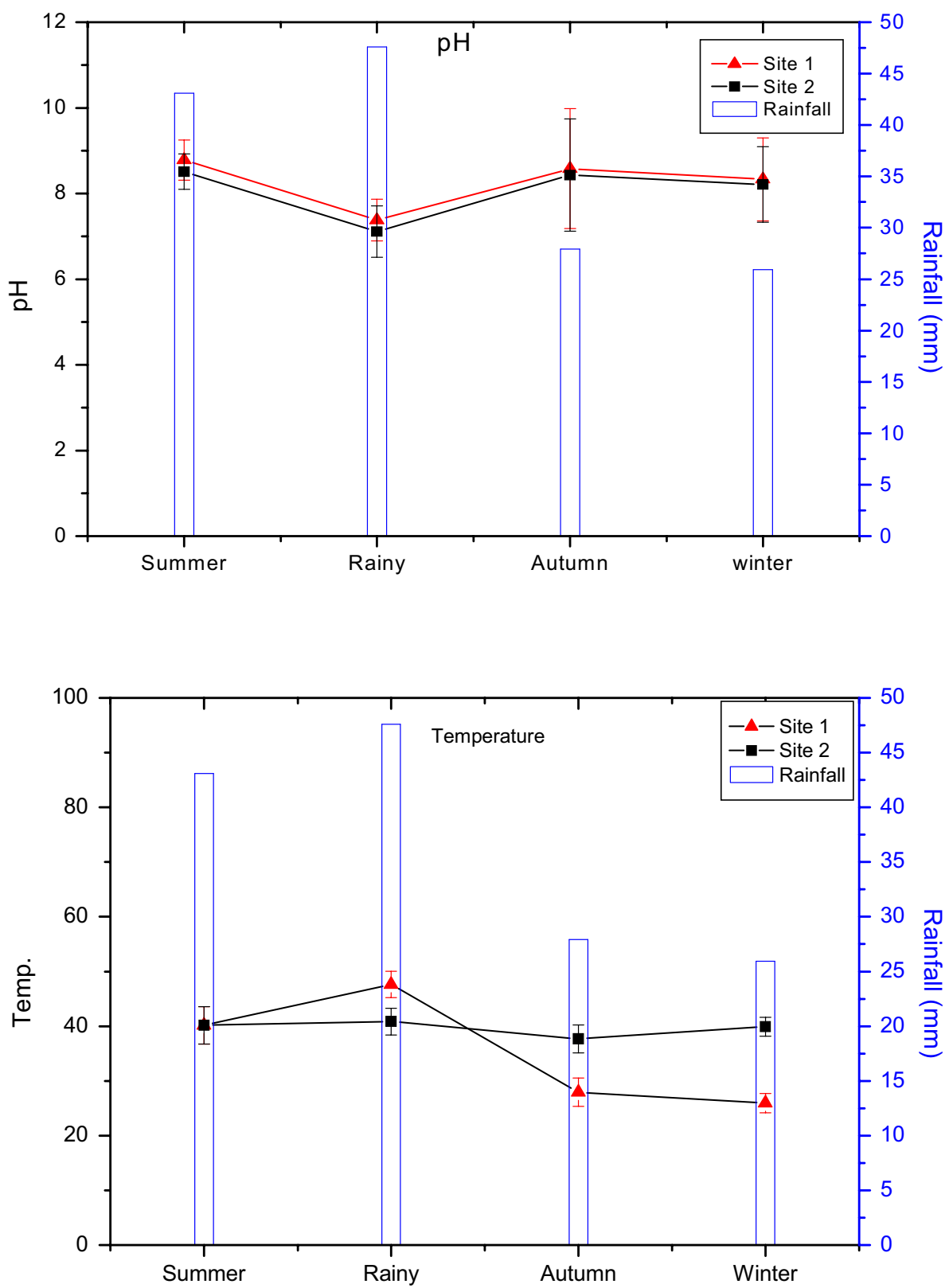

Fig. 3 Average seasonal variations of water temperature at different seasons of Site 1 and Site 2 Ludhiana, Punjab (April 2014-2015) the highest value for BOD was observed in autumn, i.e. $361.67 \pm 130.44 \mathrm{mg} / \mathrm{L}$ for Site 1 and $341.6 \pm 123.84 \mathrm{mg} / \mathrm{L}$ for Site 2 which is highly significant $(p<0.05)$. The WHO has set the limit of $250 \mathrm{mg} / \mathrm{L}$ for COD. Our study reveals, for both the site, $\mathrm{COD}$ value is greater than of permissible limit. The seasonal variation of COD can be clearly seen in Fig. 7. The maximum value for COD was observed in winter, i.e. $810.67 \pm 126.31 \mathrm{mg} / \mathrm{L}$ for Site 1 and $809.16 \pm 86.39 \mathrm{mg} / \mathrm{L}$ for Site 2 which is highly significant $(p<0.05)$. The effluents of the rainy season show COD value as high as $900 \mathrm{mg} / \mathrm{L}$, which may be due to high mineral content in surface runoff generated by the monsoon.

\section{Discussion}

High $\mathrm{pH}$ values in wastewater effluents may increase the chance of solubilization of main essential elements if released in natural water bodies and furthermore affects the aquatic life (Younas et al. 2017). Among the investigated textile effluent samples, the $\mathrm{pH}$ values were found in the range of 6.0-10.75. The effluent of selected dyeing mills is slightly alkaline in nature due to the presence of scouring and bleaching agents and due to chemicals sodium hypochlorite, sodium hydroxide, various surfactants and sodium phosphate used in mercerizing of the fabric (Paul 
Fig. 4 Average seasonal variations of total dissolved solids (TDS) at different seasons of Site 1 and Site 2 Ludhiana, Punjab (April 2014-2015)
Fig. 5 Average seasonal variations of total suspended solids (TSS) at different seasons of Site 1 and Site 2 Ludhiana, Punjab (April 2014-2015)
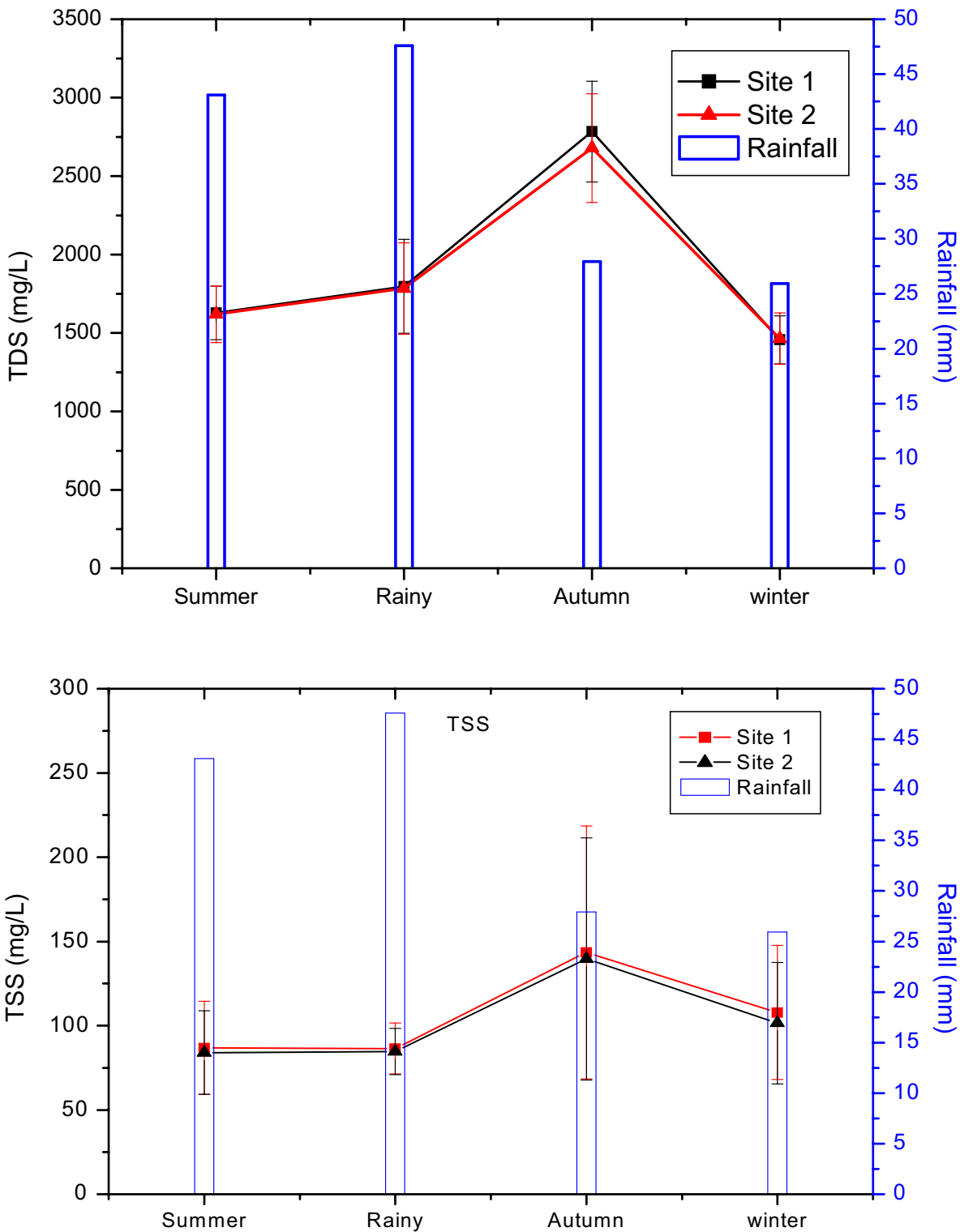

et al. 2012). Earlier similar kinds of results were obtained in textile effluents (Ramamurthy et al. 2011). pH higher than the observed range has also been reported (Desai and Kore 2011). Similar observations were also reported by Tiwari and Chauhan (2006). The low $\mathrm{pH}$ value, witnessed in the rainy season due to the accumulation of free carbon dioxide and rate of respiration of organisms, was increased due to the rise in temperature. An opposite trend between $\mathrm{pH}$ and $\mathrm{CO}_{2}$ has also been reported by Jindal and Rumana (2000) for Yamuna River. Indian rivers polluted with industrial effluents have been found to have alkaline or acidic $\mathrm{pH}$ (Gurumayum et al. 2002). This was also found to be true for river Sutlej. An earlier study conducted by Ukpaka and Ukpaka (2016) ascertained acidic pH (less than 6.5) in groundwater collected from Port Harcourt area, Nigeria, in the dry season.
If the temperature of effluents being discharged from industries is high, then it will ultimately affect the properties of land as well as receiving water body (Kolhe et al. 2009). The temperature may exert great control over aquatic life. With the increase in temperature, the rate of biological activity get altered; likewise, the solubility of oxygen and other gases will be decreased leading harmful effects on the aquatic community (Perlman 2013). The results are in accordance with the study conducted by Munnaf et al. (2014). In the present work with increasing water temperature, the concentration of dissolved oxygen decreases, and the similar findings were also reported by Mathur et al. (2007) and Pradip et al. (2012).

Total dissolved solids signify the presence of total content of inorganic $\left(\mathrm{Ca}^{2+}, \mathrm{Mg}^{2+}, \mathrm{K}^{+}, \mathrm{Na}^{+}, \mathrm{HCO}_{3}{ }^{-}, \mathrm{Cl}^{-}, \mathrm{SO}_{4}{ }^{2-}\right)$ and organic matter present in the form of a suspension in water 
Fig. 6 Average seasonal variations of biological oxygen demand (BOD) at different seasons of Site 1 and Site 2 Ludhiana, Punjab (April 2014-2015)
Fig. 7 Average seasonal variations of chemical oxygen demand (COD) at different seasons of Site 1 and Site 2 Ludhiana, Punjab (April 2014-2015)
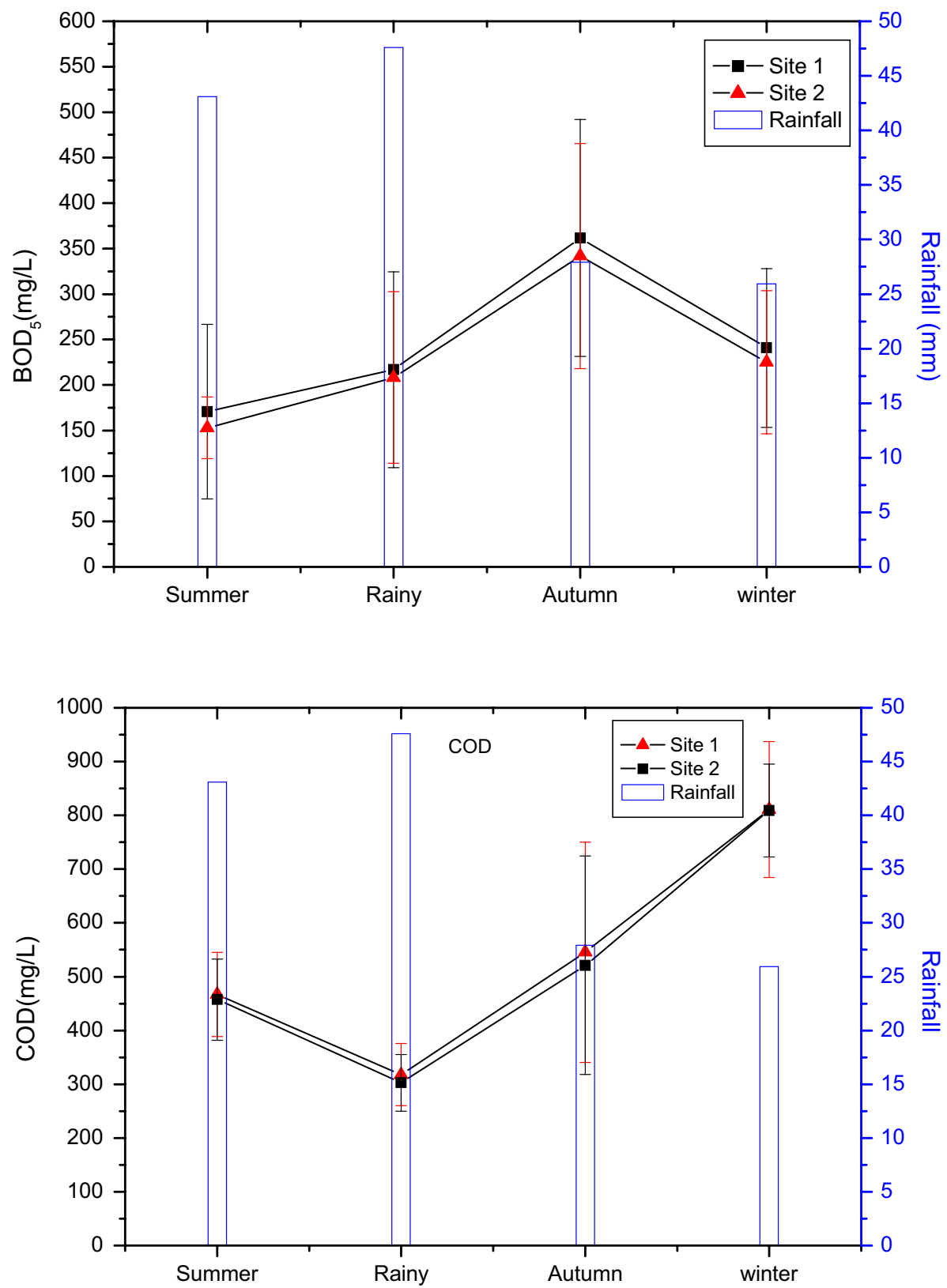

(Lokhande et al. 2011). TDS is the amount of dissolved solids in the wastewater which includes but not limited to the salts. The TDS is proportionally related to the salinity and conductivity of water. The measurement of solids is a very significant parameter if the water is being used for drinking purposes. The higher value of TDS illustrates the high rate of mineralization in water. According to the WHO standard, the limit for TDS is $500 \mathrm{mg} / \mathrm{L}$ and maximum limit is $2000 \mathrm{mg} / \mathrm{L}$ (Maruthi et al. 2004). TDS values higher in autumn and monsoon, while within the desirable limits of WHO in winter, are in support of the study conducted by Gurumayum et al. (2002). Higher values of TDS in the range of $2264-7072 \mathrm{mg} / \mathrm{L}$ in the textile effluent have been reported by Paul et al. (2012). Also, the high values of suspended solids correspond to the use of different kind of synthetic dyes (Mohabansi et al. 2011).

The earlier similar study has been conducted on Godavari River flowing little downstream from Nanded, Maharashtra, by Srinivasrao et al. (2007), and similar trends for TDS have been observed due to factors such as rainfall, which causes changes into ionic concentration and nature of the deposits present at the bottom. If the value of dissolved solids is high, it will cause salinity problem when discharged untreated to the irrigation water column (Kolhe and Pawar 2011). The excessive levels of TSS in water bodies can have significant detrimental impacts on the physical, chemical and biological properties of the water body (Bilotta and Brazier 2008). If this type of effluent is used for irrigation purposes, it will 
result in clogging of pores of soil and loss in productivity of soil (Kant 2012). Nirgude et al. 2013 reported similar findings for BOD values of textile effluent from Vapi Industrial Area, Gujarat, in the range of $90-678 \mathrm{mg} / \mathrm{L}$.

Singh et al. (2013) conducted a similar study on textile industry of Ludhiana, collected effluent from 7 different dyeing mills and reported very high values of BOD and COD, i.e. $108-790$ and $195-3050 \mathrm{mg} / \mathrm{L}$, respectively. High level of chemical oxygen demands indicates noxious conditions and presence of resistant organic impurities (Kumar et al. 2001; Rafeeq and Khan 2002).

\section{Conclusion}

The effluents from two different textile industries of Ludhiana, Punjab, India, were collected and analysed to determine the impact on the textile industry on water pollution. The water quality parameters like BOD, COD, TSS and TDS of textile effluent were found to be significantly higher than the maximum permissible limit prescribed by WHO. The results of this study clearly show that textile industry in Punjab, India, is polluting the local surface water bodies. Therefore, there is a need to develop simple, cost-effective and eco-friendly treatment systems for the remediation of textile effluents to minimize water pollution for sustainable environmental and economic development.

\section{Recommendations}

1. The concentrations of various physiochemical parameters of the textile industry effluents were determined and were found to be much higher than WHO water quality standards. Therefore, it shows the water quality status of industry effluents that is being discharged surface water bodies and its potential impacts on human diseases and aquatic life in water bodies.

This study clearly indicates that surface water/groundwater of local drain (Buddha Nallah) is getting contaminated slowly due to rapid industrialization. Therefore, it is necessary to enforce water quality regulations for industries setting up effluent treatment plants.

2. Proper treatment of textile industry effluents is needed before their safe disposal into water bodies.

3. Industries should be set up their independent effluent treatment plants (ETP) and should remain effectively operational in order to safeguard the quality of water for future generations.

4. Separate drainage system must be constructed to prevent direct discharge of industrial effluents into water bodies.
5. The disposal sites for industrial and urban wastes should be away from the residential areas in the city.

6. Strict implementation of environmental regulations is necessary.

Overall, there is urgent need to generate public awareness of the sources, extent and prevention of water pollution, and also the consequences of the impact of pollution on human health. The present study provides the baseline data and methodology for the assessment of various physicochemical characteristics of textile effluents. Periodical monitoring should be carried out to check the rise in water pollution for sustainable development in the study area.

Acknowledgements This work was supported by IC-IMPACT, DBT funded Grant: BT/IN/IC-IMPACTS/31/RK/2015-16, School of Bioengineering and Biosciences, Lovely Professional University, Phagwara, Punjab, India.

Open Access This article is distributed under the terms of the Creative Commons Attribution 4.0 International License (http://creativeco mmons.org/licenses/by/4.0/), which permits unrestricted use, distribution, and reproduction in any medium, provided you give appropriate credit to the original author(s) and the source, provide a link to the Creative Commons license, and indicate if changes were made.

\section{References}

Abbas M, Adil M, Ehtisham-ul-Haque S, Munir B, Yameen M, Ghaffar A, Shar GA, Tahir MA, Iqbal M (2018) Vibrio fischeri bioluminescence inhibition assay for ecotoxicity assessment: a review. Sci Total Environ 626:1295-1309. https://doi.org/10.1016/j.scito tenv.2018.01.066

APHA (2005) Standard methods for the examination of water and waste waters, 21 st edn. APHA, Washington

Asia IO, Oladoja NA, Pemu E (2006) Treatment of textile sludge using anaerobic technology. Afr J Biotech 5(18):1678. https:// doi.org/10.5897/AJB06.114

Bhatia D, Sharma NR, Singh J, Kanwar RS (2017) Biological methods for textile dye removal from wastewater: a review. Crit Rev Environ Sci Technol 47(19):1836-1876. https://doi.org/10.1080/10643 389.2017.1393263

Bilotta GS, Brazier RE (2008) Understanding the influence of suspended solids on water quality and aquatic biota. Water Res 42(12):2849-2861. https://doi.org/10.1016/j.watres.2008.03.018

Chaube P, Indurkar H, Moghe S (2010) Biodegradation and decolorization of dye by mix consortia of bacteria and study of toxicity on Phaseolus mungo and Triticum aestivum. Asiatic J Biotech Res 1:45-56

Chung KT (2016) Azo dyes and human health: a review. J Environ Sci Health Part C 34(4):233-261. https://doi.org/10.1080/10590 501.2016.1236602

Dadi D, Stellmacher T, Senbeta F, Van Passel S, Azadi H (2017) Environmental and health impacts of effluents from textile industries in Ethiopia: the case of Gelan and Dukem, Oromia Regional State. Environ Monit Assess 189(1):11. https://doi.org/10.1007/s1066 1-016-5694-4 
Desai PA, Kore VS (2011) Performance evaluation of effluent treatment plant for textile industry in Kolhapur of Maharashtra. Univers J Environ Res Technol 1(4):560-565

dos Santos AB, Cervantes FJ, van Lier JB (2007) Review paper on current technologies for decolourisation of textile wastewaters: perspectives for anaerobic biotechnology. Bioresour Technol 98(12):2369-2385. https://doi.org/10.1016/j.biortech.2006.11.013

Ghaly AE, Ananthashankar R, Alhattab MV, Ramakrishnan VV (2014) Production, characterization and treatment of textile effluents: a critical review. J Chem Eng Process Technol 5(1):1. https://doi. org/10.4172/2157-7048.1000182

Giorgetti L, Talouizte H, Merzouki M, Caltavuturo L, Geri C, Frassinetti S (2011) Genotoxicity evaluation of effluents from textile industries of the region Fez-Boulmane, Morocco: a case study. Ecotoxicol Environ Saf 74(8):2275-2283

Gurumayum SD, Daimari P, Goswami BS, Sarkar A, Chaudhury M (2002) Physico-chemical qualities of water and plankton of selected rivers in Meghalaya. J Inland Fish Soc India 34(2):36-42

Hader DP (2018) Ecotoxicological monitoring of wastewater. In: Häder DP, Erzinger GS (eds) Bioassays, advanced methods and applications. Elsevier Press, Cambridge, United States, pp 369-386. https ://doi.org/10.1016/B978-0-12-811861-0.00018-8

Iqbal M (2016) Vicia faba bioassay for environmental toxicity monitoring: a review. Chemosphere 144:785-802. https://doi. org/10.1016/j.chemosphere.2015.09.048

Jafarinejad S (2016) Control and treatment of sulfur compounds specially sulfur oxides ( $\mathrm{SOx}$ ) emissions from the petroleum industry: a review. Chem Int 2(4):242-253

Jindal R, Rumana HS (2000) Biomonitoring of water pollution in Western Yamuna Canal at Yamunanagar, Haryana. J Punjab Acad Sci 2(1):177-182

Kant R (2012) Textile dyeing industry an environmental hazard. Nat Sci 4(1):22. https://doi.org/10.4236/ns.2012.41004

Khan S, Malik A (2014) Environmental and health effects of textile industry wastewater. In: Malik A, Grohmann E, Akhtar R (eds) Environmental deterioration and human health. Springer, Dordrecht, pp 55-71. https://doi. org/10.1007/978-94-007-7890-0_4

Khataee AR, Kasiri MB (2010) Photocatalytic degradation of organic dyes in the presence of nanostructured titanium dioxide: influence of the chemical structure of dyes. J Mol Catal A: Chem 328(1):8-26. https://doi.org/10.1016/j.molcata.2010.05.023

Kolhe AS, Pawar VP (2011) Physico-chemical analysis of effluents from dairy industry. Recent Res Sci Technol 3(5):29-32. https:// doi.org/10.20546/ijcmas.2017.607.213

Kolhe AS, Ingale SR, Bhole RV (2009) Effluent of dairy technology. Shodh, Samiksha aur Mulyankan Int Res J 2(5):459-461

Kumar RS, Swamy RN, Ramakrishnan K (2001) Pollution studies on sugar mill effluent-physico-chemical characteristics and toxic metals. Pollut Res 20(1):93-97

Kumar V, Upadhyay N, Singh S, Singh J, Kaur P (2013) Thin-layer chromatography: comparative estimation of soil's atrazine. Curr World Environ 8(3):469-472

Kumar V, Upadhyay N, Kumar V, Kaur S, Singh J, Singh S, Datta S (2014a) Environmental exposure and health risks of the insecticide monocrotophos-a review. J Biodivers Environ Sci 5:111-120

Kumar V, Singh S, Manhas A, Singh J, Singla S, Kaur P (2014b) Bioremediation of petroleum hydrocarbon by using Pseudomonas species isolated from petroleum contaminated soil. Orient $\mathrm{J}$ Chem 30(4):1771-1776

Kumar V, Singh S, Kashyap N, Singla S, Bhadrecha P, Kaur P (2015a) Bioremediation of heavy metals by employing resistant microbial isolates from agricultural soil irrigated with industrial waste water. Orient J Chem 31(1):357-361
Kumar V, Singh S, Singh J, Upadhyay N (2015b) Potential of plant growth promoting traits by bacteria isolated from heavy metal contaminated soils. Bull Environ Contam Toxicol 94:807-815

Kumar V, Singh S, Singh R, Upadhyay N, Singh J (2017) Design, synthesis, and characterization of 2,2-bis(2, 4-dinitrophenyl)-2(phosphonatomethylamino) acetate as a herbicidal and biological active agent. J Chem Biol 10(4):179-190

Lokhande RS, Singare PU, Pimple DS (2011) Study on physicochemical parameters of waste water effluents from Taloja industrial area of Mumbai, India. Int J Ecosyst 1(1):1-9. https://doi. org/10.5923/j.ije.20110101.01

Majolagbe AO, Adeyi AA, Osibanjo O (2016) Vulnerability assessment of groundwater pollution in the vicinity of an active dumpsite (Olusosun) Lagos, Nigeria. Chem Int 2(4):232-241

Majolagbe AO, Adeyi AA, Osibanjo O, Adams AA, Ojuri OO (2017) Pollution vulnerability and health risk assessment of groundwater around an engineering Landfill in Lagos, Nigeria. Chem Int 3(1):58-68

Maruthi YA, Rao SR, Kiran DS (2004) Evaluation of ground water pollution potential in Chandranagar, Visakhapatnam: a case study. J Ecobiol 16(6):423-430

Mathur P, Agarwal S, Nag M (2007) Assessment of physico-chemical characteristics and suggested restoration measures for Pushkar Lake, Ajmer Rajasthan (India). In: Proceedings of Taal 2007: the 12th world lake conference 2007, pp 1518-1529

Mishra V, Gupta A, Kaur P, Singh S, Singh N, Gehlot P, Singh J (2016) Synergistic effects of Arbuscular mycorrhizal fungi and plant growth promoting rhizobacteria in bioremediation of iron contaminated soils. Int J Phytoremediation 18(7):697-703

Mohabansi NP, Tekade PV, Bawankar SV (2011) Physico-chemical and microbiological analysis of textile industry effluent of Wardha region. Water Res Dev 1:40-44

Munnaf A, Islam MS, Tusher TR, Kabir MH, Molla MAH (2014) Physico-chemical quality and efficiency study of textile and garments effluent. J Environ Sci Nat Resour 7(1):257-263

Nirgude NT, Shukla S, Venkatachalam A (2013) Physico-chemical analysis of some industrial effluents from Vapi industrial area, Gujarat, India. Rasayan J Chem 6:68-72

Noreen M, Shahid M, Iqbal M, Nisar J (2017) Measurement of cytotoxicity and heavy metal load in drains water receiving textile effluents and drinking water in vicinity of drains. Measurement 109:88-99. https://doi.org/10.1016/j.measurement.2017.05.030

Paul SA, Chavan SK, Khambe SD (2012) Studies on characterization of textile industrial waste water in Solapur city. Int J Chem Sci 10(2):635-642

Perlman H (2013) Water density. In: The USGS Water Science School. Retrieved from http://ga.water.usgs.gov/edu/density.html

Pradip KM, Zaidi J, Pal A (2012) Physico-chemical properties of Barua Sagar lake water, Jhansi, Uttar Pradesh India. Elixir Pollut 42:6355-6359

Puvaneswari N, Muthukrishnan J, Gunasekaran P (2006) Toxicity assessment and microbial degradation of azo dyes. Ind J Exp Biol 44:618-626

Rafeeq MA, Khan AM (2002) Impact of sugar mill effluents on the water quality of the river Godavari near Kandakurthi village, Nizamabad district, Andhra Pradesh. J Aqua Biol 17(2):33-35

Ramamurthy N, Balasaraswathy S, Sivasakthivelan P (2011) Biodegradation and physico-chemical changes of textile effluent by various fungal species. Rom J Biophys 21(2):113-123

Rawat D, Mishra V, Sharma RS (2016) Detoxification of azo dyes in the context of environmental processes. Chemosphere 155:591605. https://doi.org/10.1016/j.chemosphere.2016.04.068

Sarker BC, Baten MA, Eqram M, Haque U, Das AK, Hossain A, Hasan MZ (2015) Heavy metals concentration in textile and garments industries' wastewater of Bhaluka industrial area,

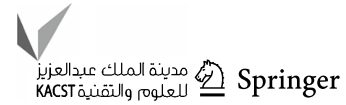


Mymensingh, Bangladesh. Curr World Environ 10(1):61. https:// doi.org/10.12944/CWE.10.1.07

Singh D, Singh V, Agnihotri AK (2013) Study of textile effluent in and around Ludhiana district in Punjab, India. Int J Environ Sci 3(4): 1271

Singh AL, Chaudhary S, Kayastha AM, Yadav A (2015) Decolorization and degradation of textile effluent with the help of Enterobacter asburiae. Ind J Biotechnol 14:101-106

Singh S, Singh N, Kumar V, Datta S, Wani AB, Singh D, Singh K, Singh J (2016) Toxicity, monitoring and biodegradation of the fungicide carbendazim. Environ Chem Lett 14:317-329

Singh S, Kumar V, Chauhan A, Datta S, Wani AB, Singh N, Singh J (2017a) Toxicity, degradation and analysis of the herbicide atrazine. Environ Chem Lett 16(1):211-237

Singh S, Kumar V, Upadhyay N, Singh J, Singla S, Datta S (2017b) Efficient biodegradation of acephate by Pseudomonas pseudoalcaligenes PS-5 in the presence and absence of heavy metal ions $[\mathrm{Cu}(\mathrm{II})$ and $\mathrm{Fe}(\mathrm{III})]$, and humic acid. 3. Biotech 7(4):262

Srinivasrao V, Khan AW, Lova Rani YVSS, Raghuram MV (2007) Variation in physical characteristic of Godavari river water at Rajamundry (A.P.). J Aqua Biol 22(2):91-95

Tiwari A, Chauhan SV (2006) Seasonal phytoplanktonic diversity of Kitham lake, Agra. Magnesium 7(17.5):8-15
Trivedy RK, Goel PK (1984) Chemical and biological methods for water pollution studies. Environmental Publications, Karad

Ukpaka C (2016) Empirical model approach for the evaluation of $\mathrm{pH}$ and conductivity on pollutant diffusion in soil environment. Chem Int 2(267):e278

Ukpaka C, Ukpaka C (2016) Characteristics of groundwater in PortHarcourt local Government area. Chem Int 2(3):136-144

Verma AK, Dash RR, Bhunia P (2012) A review on chemical coagulation/flocculation technologies for removal of colour from textile wastewaters. J Environ Manage 93(1):154-168. https://doi. org/10.1016/j.jenvman.2011.09.012

Wang Z, Xue M, Huang K, Liu Z (2011) Textile dyeing wastewater treatment. In: Advances in treating textile effluent. InTech

Younas U, Iqbal S, Saleem A, Iqbal M, Nazir A, Noureen S, Nisar $\mathrm{N}$ (2017) Fertilizer industrial effluents: physico-chemical characterization and water quality parameters evaluation. Acta Ecol Sin 37(4):236-239. https://doi.org/10.1016/j.chnaes.2017.02.002

Publisher's Note Springer Nature remains neutral with regard to jurisdictional claims in published maps and institutional affiliations. 